\title{
What is Economic Theology? A New Governmental-political Paradigm?
}

\author{
Dean, Mitchell
}

Document Version

Accepted author manuscript

Published in:

Theory, Culture \& Society

DOI:

$10.1177 / 0263276418787622$

Publication date:

2019

License

Unspecified

Citation for published version (APA):

Dean, M. (2019). What is Economic Theology? A New Governmental-political Paradigm? Theory, Culture \& Society, 36(3), 3-26. https://doi.org/10.1177/0263276418787622

Link to publication in CBS Research Portal

\section{General rights}

Copyright and moral rights for the publications made accessible in the public portal are retained by the authors and/or other copyright owners and it is a condition of accessing publications that users recognise and abide by the legal requirements associated with these rights.

Take down policy

If you believe that this document breaches copyright please contact us (research.lib@cbs.dk) providing details, and we will remove access to the work immediately and investigate your claim. 


\section{What is Economic Theology? A New Governmental-political Paradigm?}

\section{Mitchell Dean}

Journal article (Accepted manuscript*)

\section{Please cite this article as:}

Dean, M. (2019). What is Economic Theology? A New Governmental-political Paradigm? Theory, Culture \& Society, 363), 3-26. https://doi.org/10.1177/0263276418787622

\section{DOI: https://doi.org/10.1177/0263276418787622}

Copyright (ㅇ The Author(s) २018. Reprinted by permission of SAGE Publications.

* This version of the article has been accepted for publication and undergone full peer review but has not been through the copyediting, typesetting, pagination and proofreading process, which may lead to differences between this version and the publisher's final version AKA Version of Record.

Uploaded to CBS Research Portal: August २०19 


\title{
What is Economic Theology? A New Governmental- Political Paradigm?.
}

\begin{abstract}
Countering claims of its impossibility, this paper argues for economic theology as an intelligible figure of contemporary political rationality and organization, and a distinctive analytical strategy in relation to forms of liberal and neoliberal governmentality and the contemporary management of social life. As an analytical strategy, it has two arms: an institutional one, drawing upon Michel Foucault's work on the pastorate; and a conceptual one, following from Giorgio Agamben on oikonomia, order and providence. Economic theology was the arcana of twentieth-century debates on both political theology and governmentality and a condition for their emergence. It formed the horizon of Carl Schmitt's intervention of a political theology in response to Max Weber, and, as the pastorate, it was for Foucault the historical background of the emergence of the liberal arts of government. While appearing as a new paradigm, it thus has a measure of priority over our more established ones. Furthermore, to the extent that economic theology comes to occupy the place of political rationality of contemporary liberal-democratic societies, the political becomes less a rational public sphere and more a form of public liturgy.
\end{abstract}

Keywords: economy, pastorate, neoliberalism, liturgy, Schmitt, Agamben, Foucault. 
In social, cultural and political theory, we owe the most recent influential appearance of the term 'economic theology' to a thesis of Giorgio Agamben (2011: 1) that has, already, opened the space for a number of significant book-length studies (Leshem 2016; Heron 2018; Singh 2018). In Agamben's view, economic theology, which emerges with the doctrine of the Trinity, is a paradigm of 'decisive influence' on Western society and modernity. It is antinomic but functionally related to another paradigm, that of political theology. Rather than the monotheistic transcendence of the latter it offers us the idea of the oikonomia as an immanent domestic ordering of divine and human life. While political theology leads toward political philosophy and the theory of sovereignty; economic theology illuminates the rise of biopolitics with the "current triumph of economy and government over every other aspect of social life'. A theological genealogy of the economy thus completes and extends Foucault's history of governmentality.

At the heart of this thesis is the identification of the Christian Trinity as an oikonomia. The term oikonomia appears in Aristotle and Xenophon to designate the management of the household, and is a compound of oikos, the household defined in contradistinction to the polis, and nemein, or management or dispensation, the word from which nomos is derived (Agamben, 2011: 18-19; Leshem, 2016: 12-17). The term acquires further meanings around the sense of 'arrangement' in Stoic literature, especially its use to mean the ordering or arrangement of material or argument in rhetoric (Agamben, 2011: 19-20). Cicero, in this context, translates the term into the Latin dispositio, in a move that resonates with the post-structuralist figure of the dispositif (Fr) and dispostivo (It) as an internally organized 'economy of power relations' without a grounding in a supreme power or a founding structure. In the early Church Fathers (the Apologists), the term gradually assumed a tissue of theological senses including the management of the divine mysteries 
and, with Irenaeus, the plan for salvation of humans that unfolds according to fullness of the ages (Leshem, 2016: 34-35). The passage to regarding the Trinity as an economy was through the reversal of St Paul's phrase 'the economy of the mystery' hidden in God (Ephesians 3:9) to form the 'mystery of the economy' in Hippolytus and Tertullian (Agamben, 2011: 35-36; Leshem, 2016: 40-41; Heron, 2018: 26-27, 36-38). Now the term encompassed the incarnation of God in Christ and the very notion of the Holy Trinity. Its intellectual virtue is that it articulates or 'disposes' the divine Being into a Trinity, while, simultaneously, preserving or 'harmonizing' its unity, as it unfolds God's plan for salvation. It thus provides a conciliation of competing claims of monotheism in Judaism and certain Christians, such as those called the Monarchians, and the Gnostic proliferation of the 'hypostases' of God, which portends a reversion to polytheism (Agamben, 2011: 36). Thus the early Church Fathers used this complexly determined term to articulate a single semantic field that could reconcile God's being and praxis, ontology and practical-historical plan for salvation, in an account of the divine government of the world. At various times, and in different combinations in particular theologians, the oikonomia is a doctrine of the divine dispositive of three interdependent but distinct and unified persons without ultimate foundation, of a linear history with an end and the pathway to human salvation, of the prudent management of mundane, divine and sacramental resources for specific ends, and of the principle of growth of a society of believers. The key historical claim of an economic theology is that the features of this Trinitarian economy and its successors find their way into the determinate semantic and pragmatic field of the modern economy as prudential management, progress, and growth, bound together by logic of immanence, in the service of human ends, needs and desires.

For Agamben (2011: 6-15, xi), the recovery of this paradigm is something that is at stake first in the debate over the closure of political theology between Carl Schmitt and the theologian, Erik 
Peterson, and secondly, in the failure of Michel Foucault to bring his genealogy of governmentality to completion. Yet it lay in waiting from the early Christian writings and their discussion of the Trinity as a mystery of the oikonomia, to its awkward appearance in modern Protestant theology and in the German idealist philosophy of history of Hegel and Schelling (Agamben, 2011: 4-6). Yet, despite Agamben's claims, the exact nature of the 'decisive influence' of economic theology remains obscure. Theology is the study of the divine, and economics the science of the satisfaction of the profane material needs and desires of humans. While Agamben views Christian theology, and key concepts of oikonomia, providence and order, as bearers of economic logic and rationality for many of the centuries between the ancient Socratic household economics and the eighteenthcentury French économistes and the Scottish Enlightenment, he rejects a general thesis of secularization that would suggest a direct transfer of concepts from theology to political economy and prefers to emphasize the fields of 'indistinction' between theology and secular rationalities in economics and politics. In contrast, we shall entertain a somewhat stronger hypothesis here in two respects. First, economic theology is not simply a paradigm but an analytical approach, with distinct and identifiable techniques of analysis. Second, its decisive importance lies not that it represents a more recent transmutation of political theology but that it is inextricably bound to it. In a historical sense, economic theology follows and neutralizes political theology. However, as a contemporary social, cultural and political analytical and theoretical framework, economic theology has, counterintuitively, a certain primacy. It is the secret supposition for the emergence of twentieth-century political theology and, therefore, for Schmitt's intervention. In this sense, economic theology is not only the arcana of the political-theological debate but also its condition. This has led one recent authoritative account to advance the hypothesis that economic theology is the very form of a Christian political theology (Heron, 2018: 39-40). 
Before moving on to examine these claims, there are nevertheless two direct uses of the term 'economic theology' in recent thought that predate Agamben's, which should be addressed, and one that has post-dated his thesis that will deny the very possibility of an economic theology.

The first of the earlier two is found in the writings and intellectual trajectory of the American economist, Robert H. Nelson (2004), who poses the very question, 'What is economic theology?' Here, 'economic theology' commences as neither an analytical perspective nor a contribution to theology but as a historical and conceptual critique of economics and, in particular, the American economics profession. To call something an 'economic theology' in this manner is to reveal the problematic nature of the fundamental presuppositions and claims of economics either by an analogy with religious offices and artefacts (the priesthood or ministry, bibles) or by showing the historical origins of the economics profession. To substantiate his argument, for example, Nelson (2004: 59) notes that among the fifty founders of the American Economic Association in 1885, twenty were former or practicing ministers and one of the most eminent, Richard T. Ely, was also a leading member of the Social Gospel movement. More recently, Nelson's (2017) notion of economic theology has become more analytical and provides a cultural-historical analysis of the 'spirit of Nordic social democracy' in terms of the prevalence of Lutheranism in the Nordic countries, and seeks as a consequence to modify Weber's Protestant ethic thesis.

The second prior use of the term dates to the period of the Second World War and the writings of the Ordoliberal, Alexander von Rüstow. Rüstow is interesting not only as a commentator on economic theology but also as a practitioner and as a member of one of the most significant strands of neoliberalism. Rüstow (1942: 279-280) follows the idea of 'invisible harmony’ posited by laissez-faire economics from the pre-Socratics, through Stoicism and early Christianity to l'ordre 
naturel of the Physiocrats and Adam Smith's 'invisible hand'. He further compares economic liberalism to Spinoza's deus sive nature (God as nature), and to Taoism. Rüstow offers us as a critique of early liberalism as a pantheistic theology, due to its 'mistaken pseudo-universalism', and thus prepares the way for the Ordoliberal enframing of the market within a definite governmental and juridical order. Rüstow will call this pantheistic liberalism an 'economic theology', a 'Wirtschaftstheologie'. Given his demonstrated intellectual relationship with Schmitt (Ptak, 2009: 111-112), we can note that his 'Third Way' between 'broken down liberalism and collectivism' (Rüstow, 1942: 278) is one sketched between, and seeking to reconcile, economic theology and political theology, pantheism and monotheism. Some commentators have suggested (Ulmen, 1985; Palaver, 2017), that Rüstow received the notion of 'economic theology' from Schmitt and his engagement with Max Weber and that it precedes rather than follows 'political theology'.

Like Nelson, Rüstow uses the term 'economic theology' as a critical one, observing theological aspects of modern economics and economic policy, although his target is early liberalism rather than the economics discipline and profession. However, given his role in the Ordoliberal movement, and the recognition of the centrality of the latter both to contemporary neoliberalism and in the formation of the post-war German state and the European common market and currency (Foucault, 2008; Ptak, 2009; Hien, 2017), it is not surprising that analysis linking neoliberalism with economic theology would emerge under the recent 'spirit of austerity' (Konings, 2016).

What was not expected was that the dénouement between theology and neoliberalism would come from pushing back the theological genealogy of economy from early modern to late antique times (Leshem, 2016) nor that it would take the form a challenge to the very idea of an economic theology. Drawing on the Eastern Fathers between and around the Councils of Nicea and Chalcedon 
of the fourth and fifth centuries, Dotan Leshem (2016) has argued that the developments at that time make an economic theology impossible. Theology and economy, after this crucial moment, refer to quite different domains: those of 'the internal organization of the triune Godhead in the case of theology and the worldly manifestation of God in that of the economy (Leshem, 2016: 7, 41). This view is supported by the earlier study of Marie-José Mondzain (2005: 22-26) in her understanding of the relation between icon and economy in the seventh and eighth centuries in which theology deals with divine substance. Every attempt to approach that substance meets 'a wall' which seals off a mystery that escapes every word and comprehension, while economy deals with God only in so far as he makes himself known to humans. Hence the need for the icon.

No sooner had Agamben reopened up the case of an economic theology, than he meets arguments that the case has long been closed, at least from a theological perspective. This is a something like a reprise of the debate between Schmitt and Peterson on political theology. Some thirteen years after Schmitt had used the term political theology in the title of his book on sovereignty, Peterson announced "the theological impossibility of "political theology"' (2011:234) with the development of the doctrine of the Trinity, which ensured that every political theology was 'theologically dissolved' (2011: 103-104). For Peterson, however, it is not the caesura between theology and economy but the lack of an analogue of the triune God in the created world that makes political theology impossible (Peterson, 2011: 103; Heron, 2018: 2-3). Added to this is the rejection of the concrete political eschatology of the Pax Romana in St Augustine's theology of peace that opens the possibility of a secular politics by deferring the end of time and the coming of the kingdom of God (Peterson, 2011: 104). For Peterson, it is the rejection of a worldly political eschatology, that opens up the eschatological bureau of the Church. 
Most significantly, Peterson's countering of the political use of theology was not to dismiss theological politics but to confine it to the Church with a view to understanding the 'political action' specific to the Church itself, which is found in its assemblies and liturgy. Thus, the liturgy of the Church is derived from the leitourgia (Gr.) or obligatory public service conducted in the ekklēsia, the assembly of citizens, (Peterson, 2011: 38). Moreover Peterson (2011: 96) spoke of, but did not elaborate, a 'divine economy'. The present paper follows Peterson in two respects. First, it takes up this latter indication to argue that an economic theology is possible: for example, the salvific praxis of the Trinity finds its analogue in the economic management of classical and contemporary liberal societies. Second, that if an economic theology based on a triune God rendered 'monotheistic' political theology impossible, this does not mean that political-religious action ceases to exist. Just as Peterson located such political action in the liturgies of the Church, today we need to specify the new locale of what Nicholas Heron (2018) has recently called 'liturgical power'.

This article thus takes up the challenge of the claim of the impossibility of economic theology. It next seeks to learn from the political-theological debate. This leads it to propose the dual nature of an institutional and a conceptual economic theology. In the course of the exposition, analytical tools such as analogy, signature, and the $\operatorname{arch} \bar{e}$, are identified and elaborated, as too are exemplary cases, such as order and providence. Economic theology is further understood through historical or, more properly, genealogical and archaeological projects, and the relationship between these two projects is imagined and sketched. In a concluding section, we will return to the crucial relationship between contemporary economic theology and the form of political action. This relationship is specified there but the task of elaboration has begun to be conducted elsewhere (Dean 2017b). 


\section{Political theology and economic theology}

Many modern uses of the term political theology trace their origins back to Schmitt's 1922 book (2005), Political Theology. Apart from the preface to the 1934 edition, it is surprising that the term appears only a few times in this seminal text. The major specification of the term does not appear until the beginning of its third chapter. There, it concerns the parallel between political and theological-metaphysical concepts and is summed up as the thesis: 'All significant concepts of the modern theory of the state are secularized theological concepts not only because of their historical development...but also because of their systematic structure, the recognition of which is necessary for the sociological consideration of these concepts' (Schmitt, 2005: 36). While the relation between a single God and 'omnipotent lawgiver' is an example of the process of historical development, the exception in jurisprudence is analogous to the miracle in theology. Schmitt thus posits an approach that is broadly conceptual and analogical in character, posing 'a systematic analogy between theological and juristic concepts' (2005: 42). He also views his contribution as being within the newly emergent sociology of law that rejects spiritualist or materialist approaches and causalities, and adopts a rigorous method of analogy. Thus 'the metaphysical image that a definite epoch forges of the world has the same structure as what the world immediately understands to be appropriate as a form of its political organization' (Schmitt, 2005: 46). Twelve years later, Schmitt notes importantly that Protestant theology understands itself as an unpolitical doctrine "just as in political liberalism the state and politics are conceived as the "wholly other"" (2005: 2). The latter observation thus locates economic theology as a kind of impolitical theology and like Weber places Protestantism at its epicentre. Nevertheless, this first version of political theology rests principally on a synchronic sociology of juristic concepts that identifies systematic, or, as we might say, 'structural', analogies between the theological-metaphysical and juridical- 
political concepts of a particular society. The relation is 'sociological' for Schmitt in that it follows Weber's (1948: 280-281; Boland and Griffin, 2017: 3) discussion of the radically transformative effects of what he calls certain 'world images', that can act as 'switchmen' by determining the tracks for action. Like Weber, Schmitt proposes a relation between metaphysical, often religious or theological, images of the world and normative political organization and concepts, and the way in which crises can act as occasions for the changing hegemony of such images.

One year later, Schmitt published another book on political theology, Roman Catholicism and Political Form (1996). This book advanced the fundamental thesis of the historical relationship between the juridical rationalism of the Roman Catholic Church and the form of the modern state (Ulmen, 1985: 27-29). Schmitt views the crucial political practices of form, representation and office as descended from the Catholic Church. The latter at once combines the aesthetic form of art, the juridical form of law and the glorious form of world-historical power (Schmitt, 1996: 21). It is this majesty of the public manifestation of the Church that will be rejected by Protestants in the name of inwardness and individual conscience and faith. The Pope's office is at once a rationallegal form and a personal form of authority. As Vicar of Christ, it is literally a 'vicarious' office independent of the individual occupying it (Schmitt, 1996: 14). But the position is not impersonal and depends on 'the unbroken chain linked with the personal mandate and concrete person of Christ' (Schmitt, 1996: 21). For Schmitt, the Church thus bequeaths to the modern state both the principle of representation and the form of rational-legal authority and hierarchy of bureaucratic offices. In this second book, he thus offers a kind of genealogy of political or institutional form from canon law to the modern state that complements the earlier sociology of juristic concepts. 
Schmitt's relation to sociology, however, is perhaps even closer in the latter text. On close reading, this text acts as a complement and, to some extent, corrective to Weber's Protestant Ethic and the Spirit of Capitalism (1985). Weber's sociology here can be legitimately regarded as an economic theology in that it proposes the effects of theological doctrines and world-images into the practical domain of the economic conduct of life. He does this by showing how Protestant individualism and asceticism, particularly in Calvinist doctrines of predestination and work in a 'calling', promoted a conduct of life (Lebensführung) amenable to capitalist economic acquisition and its division of labour. In that sense, Weber offers us a practical or institutional economic theology rather than a conceptual one. Contra Weber, Schmitt would seek a relation between the public manifestation and substantive form of Catholicism and the durability and impersonality of the modern state. More sharply, Schmitt juxtaposes two secularizations or rationalizations in which the economic rationalization and 'disenchantment' Weber proposes neutralizes the political rationalization of canon law in the juridical form of the modern state. As Ulmen (1985: 28, original emphasis) points out, for Schmitt 'the economic ethos promoted by Protestant asceticism was fundamentally antagonistic to the political ethos of Catholic decisionism, even as the liberal concept of culture was fundamentally antagonistic to the concept of culture that rose from the modern state'. The term, 'Catholic decisionism', refers to the ultimate authority of the Pope over the worldly Church, though vicariously derived from Christ himself.

Schmitt and Weber's cultural diagnostics of modernity also thereby differ. For the latter, rationalization means that modern culture loses its spiritual bearings and that the 'light cloak' of Baxter's Puritanism becomes 'an iron cage' (Weber, 1985: 181). For Schmitt, in contrast, the neutralization of the state form means the continuation of confessional civil war by other means in which liberalism will conduct a war on the political itself, but 'never produces a positive theory of 
state, government, and politics' (1996: 70). If Weber offers a diagnosis of what will become the Fordist capitalist welfare state and its bureaucracy, Schmitt's view may be more apt to the debates over the clash of diverse cultures in the European debt crisis (Hien, 2017), and, by extension, the neoliberal wars on the very notion of a separate domain and mode of truth-telling of the public sphere and public office, and the contemporary reassertion of sovereignty and nation in authoritarian and populist versions of democratic politics. In other words, contemporary America looks more like the continuation of deep-seated confessional conflict than a society of disenchantment and soullessness. According to the French president, Emmanuel Macron, Europe has entered a 'civil war' between (neo)liberal and illiberal democracy (Erlanger, 2018).

This detour via the emergence of political theology reveals first of all the possibility of a conceptual and an institutional political theology, and thus foreshadows the possibility of both a conceptual and institutional economic theology. It secondly places political theology in relation to economic theology, with the latter partially charted as the neutralization of the former, and connected intimately with liberalism. It thirdly forces us to note that Schmitt's notion of political theology emerged out of what might already be considered an economic theology - Weber's Protestant ethic thesis (Ulmen, 1996: xix-xxiv). Economic theology is thus a condition of emergence of a political theology but is itself already an impolitical political theology.

\section{Institutional Economic Theology}

An institutional theological genealogy would be concerned to show the various historical multidirectional trajectory that link social patterns of conduct, techniques, practices and forms of organization and ecclesiastical, ascetic, monastic, liturgical and other religious practices. In most influential cases, the movement is in the direction of 'secularization', although that cannot be a 
necessary supposition. For example, Weber (1985) proposed that Calvinist religious belief and practice favoured a practical conduct of life that embraced and glorified life in a calling and thus unintentionally promoted regular work and rational economic acquisition without idleness, luxury or vain expenditure. In that this form of life conduct promotes a certain kind of economic action with an affinity with capitalist economic organisation, it could be said to contribute to an institutional economic theology.

Michel Foucault's wide-ranging discussion of the genealogies of pastoral power and forms of confession could also be said to follow the path of institutional theology - although Foucault himself largely neglected its economic character. Foucault offers us both a detailed (2007) and a series of more general accounts of what he calls pastoral power (e.g. 2001: 298-312), which encompass the relation between the shepherd or pastor and flock or members of a religious community in both Eastern, particularly Judaic, and Christian forms. For Gregory of Nazianzus, Foucault tells us, the pastorate was the techne technon, episteme epistemon, the "art of arts,", the "science of sciences"” (2007: 151), that is a technology for the formation of conscience and obedience and the guidance of humans toward salvation. In Foucault's most extended account over five lectures in his genealogy of governmentality, Christianity gives institutionalised form of the pastorate in four ways (2007: 169-183). First, it establishes the radical accountability of the shepherd for his flock, which includes the possibility of his sacrifice for them. Second, the shepherd and flock are bound in relations of 'pure obedience'. Third, via the take-up and use of ancient ascetic practices, the shepherd requires an in-depth individualizing knowledge of each member of the flock. Finally, the members of the flock engage in practices of self-mortification to renounce the things of this world for the grace to enter another. More generally, following Jeremy Carrette (2013: 
375), pastoral power is exercised over a flock, beneficent leading to salvation, dutiful on the part of the shepherd, and individualizing on each member.

This detailed examination is, however, marked by a degree of equivocation and not a little embarrassment on Foucault's part about the length of time devoted to the subject. At the beginning of the fourth lecture on the topic (Foucault, 2007: 193) he forces himself to ask the question of 'how the problem of government, of governmentality, was able to arise on the basis on the pastorate'. In this sense Foucault clearly wants to demonstrate that the institutional genealogy of modern government grows out of the figure of the Christian pastorate (Carrette, 2013: 375). The lecture itself offers no clear answer to this question. In it he attempts to get close to the crucial crossover between pastoral power and modern governmentality by considering the 'immediate and founding correlation between conduct and counter-conduct' in 'the great age of the pastorate' from the tenth to the seventeenth centuries (Foucault, 2007: 196-197). The lecture is in considerable part a long discussion of these counter-conducts, which include practices founded on asceticism, communities, mysticism, the Scripture itself, and eschatology (Foucault, 2007: 204-214). When he returns to consider what this discussion has achieved in terms of his central genealogical objective, he seems content with the explanation that he had only sought to give 'the inner depth and background of the governmentality that begins to develop in the sixteenth century' (Foucault, 2007: 215).

If the specific institutional genealogy ends in irresolution, the purpose is clear. Foucault aims at a more general thesis on the relationship between the pastorate and modern government. The pastorate is 'integrated' into his account of modern governmentality, not 'transitional' to it (Carrette, 2013: 373). Earlier in the lectures, he argues that the multiple and intense problems of government from the sixteenth century were occasioned by the intersection of two movements, one 
of the state centralization that emerged from the breakdown of feudalism and the second, concerning spiritual direction, of the 'religious dispersion and dissidence' emerging with the Reformation and Counter-Reformation (Foucault, 2007: 89). In 'The Subject and Power' (Foucault, 2001: 333), he responds to the claim that 'the pastorate has, if not disappeared, at least lost the main point of its efficacy' by arguing that he wants to distinguish between two aspects of pastoral power: 'the ecclesiastical institutionalisation that has ceased or lost its vitality since the eighteenth century, and its function, which has spread and multiplied outside the ecclesiastical institution'. If we were to put Foucault's thesis on the pastoral power another way, it would be that the loss of the monopoly of the pastorate by a universal Church during the Reformation released its contents onto a range of non-religious sites and forms of expertise.

Foucault thus hopes to complete a genealogy which shows that the notion of salvation is reborn as 'health, well-being... security, protection against accidents' (2001: 334) and in which pastors are found in the state, private philanthropy, and in the complex public and private structures of professions such as medicine. Professional expertise, forms and knowledge, kinds of therapy and counselling, and social and political institutions are thereby linked to the transformation of the religious institution of the pastorate. There is, however, only a single indication that this theological genealogy is an economic one. Foucault notes that that Gregory of Nazianzus calls the pastorate the economy of souls, an oikonomia pyschōn (2007: 192). He dwells only briefly on the Greek notion of oikonomia here in relation to the management of the household, the oikos. Instead he points out that the economy of souls changes 'dimension' from the oikos to focus on the 'whole Christian community and on each Christian in particular', and has its point of reference not in the prosperity of the family but in the salvation of souls. In the very next paragraph, he translates oikonomia as 'conduct', which becomes the key to his understanding of government as the 'conduct of conduct', 
and which, to a large extent, throws his genealogy off balance in that it suppresses the history of the economy for fourteen centuries. It is perhaps symptomatic that Foucault does not regard liberal economic government as a form of salvific pastoral practice, but as the means by which pastoral and biopolitical rule can be tested under the suspicion 'on gouverne toujours trop' - one always governs too much (2008: 319). In other words, Foucault's genealogy of governmentality falters at the point at which it regards the liberal economy as a mode of 'veridiction', a form of critique, a test or method, by which pastoral rule in limited rather than being the precise field into which the Christian pastorate has migrated.

Giorgio Agamben (2011: 110) justifiably sees this latter move as indicative of Foucault's failure to appreciate the theological implications of the term 'oikonomia'. However, in so doing Agamben perhaps dispenses too quickly with the consideration of the pastorate in his own theological genealogy, that is with the understanding of Christianity as a church or ekklēsia, to follow Peterson's (2011: 38) use of the Greek term to designate the 'fully enfranchised citizens of a polis, gathered together to perform legal acts'. Dotan Leshem (2016) has used this same very small window in Foucault's text to demonstrate the continued relevance of Foucault's analysis to the theological genealogy of the oikonomia. He offers an important reformulation of Foucault's genealogy here when he suggests that the pastorate might be more usefully understood as an 'ecclesiastical economy' (Leshem, 2016: 6), animated by the principle of growth. In Leshem's account, the pastorate, in the fourth and fifth centuries, is shaped by the way the incarnation of Christ acts as a paradigm for the mimetic relation of human conduct to divinity. Pastoral governing thus contains a 'constitutive excess' (Rust, 2017) in that the ecclesiastical economy is a space of believers that transcends human reason due to the full communion and complete interpenetration (technically, the 'perichoresis') of the human and the divine in the economy (Leshem, 2016: 56). 
This excess activates a surplus and principle of growth in that individuals are purified and included in an expanding community of believers who follow and seek to imitate Christ. Leshem's account shows how the ekklessia, originally the sphere of public assembly opposed to the household or oikos from classical Greece, takes on an economic form in the economy of the incarnation. Accordingly, the ecclesiastical economy transforms the nature of excess from Nature to God, the prudent manager from the head of the household to the pastor, and the use of the surplus from participation in politics and philosophy to augmentation and therefore growth of the economy itself. While, with one exception, Leshem does not explore the material aspects of the 'ecclesiastical economy', there are key structural analogues in modern conceptions of government that base themselves on ideas of inclusion within labour and other markets, the construction of markets as a solution to problems of public provision, and the fostering of prudential forms of conduct as a condition of continued economic growth.

The exception occurs within the movement from an ecclesiastical economy to a classical liberal market economy. Leshem (2016: 160-161) here relies on Hannah Arendt's observations (1998: 248251) concerning the Reformation as a process by which the Church was stripped of its material property, which was subject to individual expropriation and social accumulation, and which then began to remove the public character of ecclesiastical spaces. He then supplements her account by showing how this was accompanied by a stripping of the ekklessia of its intangible assets, the society of believers in Christ's economy. Both such secularizations of ecclesiastical assets left the pastorate free to be overtaken by another economic activity (Leshem, 2016: 162). Thus, a condition for the emergence of a generalized market economy was the loss of monopoly of faith in Christ's economy of salvation that would be realized in the fullness of time and its replacement by a limitless growth without end founded not on the Godhead (as it was since Gregory of Nyssa) but on unlimited 
human wants pursuing unlimited satisfaction in their objects. What we view as the emergence of the liberal market economy is, according to Leshem (2016: 171), 'the transposition of the society of believers in the economy from the ecclesia to the market by changing the origin of the excess economized and the nature of the surplus generated by it'.

By retaining the economizing dimension of Foucault's pastoral power, Leshem thus reveals a theological genealogy that links the institutional structures of the Church with those of economic liberalism and the market. He suggests some very broad lines of a theological genealogy of the economy not so much as a concept but as an institution or institutional practice. In this respect, he demonstrates the centrality of ecclesiology to the problem of the market that confirms Ernst Kantorowicz's claim (1955: 66) that 'sociological problems began to shape ecclesiastical problems and, vice versa, ecclesiology, sociology'. What has occurred, for Leshem (2016: 168), is 'not a clear and simple secularization of Christian society but a radicalization of the Christian theory of economic growth, which now holds that each and every object (and no longer only the Divine One) possesses the ability to generate in humans an unlimited, unsaturated desire'. Recalling Rüstow, he concludes that the market economy ascribes the divine ability to generate insatiable desires to all objects, 'the divinization of each and every object of desire' in an 'anarchic pantheism' (original emphasis).

The pay-off for the genealogy of pastoral power is this: rather than view economic liberalism as a test, critique, or limitation of the totalizing imperatives of (pastoral) governmental authority, we should regard it as the very carrier of the theological tradition that places the notion of a divine sovereignty in communication with a divine economy that also came to describe the boundaries of the Church. The main analytical point that we can make is that the genealogy of the economy can 
be located within an institutional economic theology because it seeks to demonstrates the relationship between the market economy and the ecclesiastical economy, and reminds us that the latter was already a result of a series of innovations on the ancient household economy. The intelligibility of such an institutional economic theology depends, however, on a conceptual economic theology.

\section{Conceptual economic theology}

According to Schmitt, all conceptual political theology proceeds by a rigorous and systematic analogy between theological and political concepts. Indeed, analogy is precisely the method used by Nelson and Rüstow in respectively making the case that modern economics and early economic liberalism are fundamentally shaped by or share similarities with theological concepts. But, beyond its headline-grabbing capacity, can analogy be regarded as a serious method?

Analogy provides us with a first insight and intuition into economic theology but it needs to be handled carefully (cf. Singh, 2018: 17-22). In this respect, Agamben is again instructive (2009: 1920). Relying on Enzo Melandri, he suggests that analogy is opposed to dichotomous logic. The analogical third is a way of living with and using, rather than resolving or overcoming, a dichotomy. Analogy thus intervenes into dichotomies not to create a dialectical resolution in a higher synthesis but 'to transform them into a force field traversed by polar tension, where...their substantial identities evaporate' (Agamben, 2009: 20). The point of analogy is thus not to show that A determines $\mathrm{B}$, or that $\mathrm{B}$ escapes $\mathrm{A}$, nor that the opposition between both is transcended by $\mathrm{C}$, but that A and B exist in a field of 'vectorial intensities' of relations of attraction and repulsion. The use of analogy then is a method that demonstrates the existence of such a field and the ultimate un- 
decidability or indiscernibility of the boundaries between the terms that define the poles that constitute such a field.

If Agamben allows us to begin to specify what we might mean by analogy, it is the next methodological step, that of identifying 'signatures', that helps provide an adequate understanding of the 'basic, radically systematic structure' that links different conceptual domains, including but not restricted to, the relation between theological and mundane concepts (Schmitt, 2005: 43). There are two key elements here. First, a signature is something that above all marks a concept or a sign and places it within a definite pragmatic and interpretative field of relations (Agamben, 2009: 40). Like the 'statement' in Foucault, it is irreducible to the semiology that allows us to recognize signs or the hermeneutics that enables us to discover their meaning. A signature may be a word or concept - oikonomia for instance - but it can be an act, gesture or performance that places a concept or sign within a definite set of semantic and practical relations. Such acts would include the blessing of an infant's forehead with water during baptism, the raising of a hand in oath-taking, the tripartite structure, timbre and cadence of the voice in hymns and chants such as the medieval laudes examined by Kantorowicz (1946).

Secondly, and more importantly, the signature is also that which allows the movement of concepts from one domain to another without material transformation of the relations of which they are a part. This movement may be within the ceremony or liturgy itself. Thus, the baptism cleanses the soul of the infant of the state of original sin to be admitted to the Church in a state of purity. The assertory oath (e.g. 'I swear I was in Copenhagen yesterday') in a court of law suspends the content of the assertion to include it in a legal testimony. The laudes (or praises, such as of the Christus vincit type analysed by Kantorowicz [1946]) devote the content of what is sung to a glorification of 
the divine. The political acclamation marks a phrase ('the PEOPLE, UNITED, will never be DEFEATED') or even a name ('O-BA-MA, O-BA-MA, O-BA-MA') in the formation of a public, a people, or consensus. The movement however is also a more general one across domains. Thus, a signature allows the movement of a concept or sign across the boundaries of the sacred and the profane (or vice versa) without materially altering the field of semantic and pragmatic relations in which it is inscribed. There are thus isomorphic relations between liturgical chants and political acclamations, ordination oaths and coronation oaths, and between the ecclesiastical economy and market economy. For economic theology, the identification of signatures seeks to make possible the analysis of the movement of terms such as those associated with economy from the ancient oikos to the Christian ekklessia, and from the theological domain to the mundane world of modern economics.

The signature can also take the form of a combination of words, a syntagma. 'The God/King reigns, but does not govern' is a particularly durable one that captures the signature of the field of relations between transcendent and immanent powers, and with small variations, marks the a field of reversibility, oscillation, opposition and indifference, between the theological and the political, the divine and the mundane, the sovereign and the governmental, the monarchical and the liberalconstitutional, and the political and the economic (Dean, 2012; Whyte, 2013; Singh, 2015; Heron, 2018). The 'invisible hand' acts as a signature in Smith in that allows a crossing between Stoic notions of an omnipotent and beneficent providence to be found in his discussion of those lacking the 'necessaries of life' in his Theory of Moral Sentiments (2002: 215-16) and the immanent 'order' that harmonizes the pursuit of self-interested gain behind the back of each individual in The Wealth of Nations (1976: 456). It thus allows a movement between a transcendent domain and an immanent order, between a domain of divine providence and the natural 'economic' order of mankind. But 
now the mundane order is not the quotidian administration by the sovereign's delegate or official, such as in a constitutional monarchy, but the governing by a form of nature itself. If Smith thus effects a kind of secularizing move with this signature, its invocation today is often an attempt to sacralise the mundane domain of economic activity, competition and consumption, and to mark it as a sacred sphere of political inviolability.

The fundamentals of a conceptual economic theology are then first to observe analogies, second, to identify signatures, and finally to demonstrate the way those signatures allow the movement of concepts across the sacred and the profane, or theological and economic and political domains, in both directions. Contra Schmitt, Hans Blumenberg (1985: 92-93) was right to suggest that the mere presence of a previously theological concept is insufficient to demonstrate a political (or, in the present case, economic) theology. What the methodological injunction to identify signatures does is to demand the analyst constructs the systematic field of linguistic and non-linguistic elements, of discursive and non-discursive practices, of signs and social practices, in which these concepts are placed, and which maintain the same or similar fields of relations despite their movement to a new domain. The next section provides two extended examples of a conceptual economic theology in relation to the reciprocal movements of genealogy and archaeology.

\section{Genealogy and Archaeology}

Agamben (2009: 98-99) presents us with an arresting image of two angels: one derived from Enzo Melandri's observation, after poet, Paul Valéry, that 'we enter the past backwards', and the second from Walter Benjamin's ninth thesis, of the angel of history caught in the storm of progress with its face to the past. 'If the latter advances toward the future with a gaze fixed on the past, Melandri's angel regresses into the past while looking at the future' (Agamben, 2009: 99). The goal of both 
these movements is the present, the point at which 'these gazes encounter each other, when a future reached in the past and a past reached in the future for an instant coincide'. This image neatly condenses the view that historical analysis can work in two different directions, which we might call a genealogy that seeks to recover the present as a series of transformations that emerge from the past, and an archaeology, that reaches through current problems towards a receding past to discover the 'moment of arising' of a distinction, the archē.

In respect to our concern for economic theology, the first possibility starts with the historical archive and seeks to trace, in a classical genealogical fashion, the trajectories of theological concepts in the direction of the future to glimpse our evanescent present. Largely this is the approach to the theological genealogy of the economy that could be derived from Agamben (2011), Leshem (2016) and Mondzain (2005) who, taken together, provide a genealogy of the oikonomia from the oikos in classical Greece through Imperial Rome, early Christianity, the eastern Patristics to the problematizations of the icon in the seventh and eighth centuries. The second angel (Melandri's) regresses toward the past with eye on the future. It starts from problematizations in the present, examines current and recent debates, and uses them to push further into the past. This move might be considered archaeological in that it seeks an $\operatorname{arche}$, a 'moment of arising' before the emergence of a distinction, say, between the theological and the economic, or the religious and the political. It is not an anachronistic move because it does not project the present onto the past, or read the past through the present, but analyses how contemporary problems, debates, and theories use, take up and transform concepts from the past. In Melandri's terms, 'the regressive operation is the exact reciprocal of rationalization' (cited Agamben, 2009: 98). Let us sketch exemplars of both these from the viewpoint of a conceptual economic theology. Having covered the oikonomia 
already, we shall focus on order and providence, two key terms in the carriage of economic theology into our present.

To start with Melandri's angel, let's turn its gaze toward the problematic of order. Order is one of the most difficult concepts to understand precisely because it seems to be an empty signifier in phrases such as social order, political order, international order, world order and, of course, economic order, market order, etc. With our gaze on the future, we might question what will become of the neoliberal order in Europe, if by that adjective we conjure up the dominant political and economic order of the most recent decades, faced with current populist and nationalist insurgencies and trenchant fiscal and debt problems. We can soon observe that order-thinking is at least fundamental to one key strand of neoliberalism (or proto-neoliberalism) analysed by Foucault (2008), the German Ordoliberals, influential on the formation of both the German state and the European Union. This could lead us to an investigation of the role of Ordoliberal thinking and concepts such as Ordnungspolitik and Ordnungsrahmen (literally, 'policy of order' and 'frame of order') in the 'Greek debt crisis' of the current decade, and the lineage of this thinking in Protestant theology and ethics (Hien, 2017). More broadly, this archaeological movement would note the intensive and multi-confessional (Catholic as well as Protestant) reflection on the concept of order in 1930s Germany across economic, legal, and theological disciplines, and the communication between them. To take the most obvious example, the Ordoliberals moved the form of the market from the order of nature to an economic and governmental order (Foucault, 2008; Ptak, 2009). Competition in the market is a kind of underlying essence or eidos that will only appear and produce its effects under certain conditions that have to be carefully cultivated and managed within a specific governmental order. This governmental order is itself encompassed by a specific 'juridical order', which might be glossed as the 'rule of law'. There is thus a simple step to view the 
Ordoliberal economic-managerial ordering of human life in a Vitalpolitik (Foucault, 2008: 148) in terms of the Schmittian (2004) notion of concrete legal order from which are derived notions of justice and legal norms. It is next possible to begin to grasp the signature of this now multidimensional concept of order in the way that theologians and philosophers such as (Catholic) Hermann Krings in 1941 would understand a divine order (Agamben, 2011: 88-91). There, the relation between God and his creatures (the ordo ad deum) is only revealed by the immanent ordering and arranging of the relation of creatures among themselves (ordo ad invicem). More generally, just like the competitive market and the juridical norm, God's order is only revealed through not the nature of his being but his practical activities of 'finishing, forming and ordering' (Krings in Agamben 2011: 89). We begin to unfold no doubt complex relations and tensions between a competitive market made possible through this particular economic order, a form of right and law that arises from a concrete order, and a negative theology in which God can only be glimpsed through the immanent order of his creatures.

The concept of order is thus not an empty signifier but a signature that allows these thinkers to move between the mundane and the super-mundane, and the immanent and the transcendent, even if it to accent one pole at the expense of the other. One can note 'the strong ties' to Protestantism of Ordoliberals thinkers (Hien, 2017: 4). But one can also note how its founder, Walter Eucken, did not neglect to cite to his father, R.C. Eucken, Nobel-prizewinning philosopher of religion, in the Foundations of Economics (1950: 325, 347), and found 'soulmates' in the Protestant priest and resistance activist, Dietrich Bonhoeffer, and Constantin von Dietze, an economist and Protestant theologian and functionary. A key part of the movement toward the past concerning order must consider its provenance in medieval Scholasticism, Thomas Aquinas, and Augustine. There are also other branches of this genealogical tree that a conceptual economic theology of order could follow 
from Friedrich Hayek's conception of 'spontaneous social orders' to the Scottish Enlightenment father, Adam Ferguson (Hill, 2006), to Stoicism and deism. What is crucial is not to try to resolve all of this into a consistent lineage but to identify the signatures that give orientation to an entire semantic and discursive field, its conflicts, contradictions, and even caesurae and confessional oppositions, and make possible particular positions within that field.

Turning now to Benjamin's angel, who is swept toward the future while gazing on the past. Our exemplar here is the notion of providence. The term has a major presence in the discussion of fate in Stoic and other ancient philosophy from Chrysippus and Alexander of Aphrodisias to Plutarch (Agamben, 2011: 114-139). The elaboration of the providence-fate distinction was bequeathed to Christian theology through Boethius's Consolations, which distinguished between providence as 'divine reason' itself and fate as 'the planned order inherent in things subject to change' (1969: 104). In Thomas Aquinas this is combined with a teleology in which the providence of first causes is designed to lead humans, through their free will or self-government, to their own salvation, thus already outlining the figure of liberal governing through the freedom of individuals, which will be taken up by studies of governmentality. Having established the necessary space of first causes as general laws, God. like the liberal sovereign or state, cannot revoke or change them. However, he can intervene in the contingent space of secondary causes; the pre-eminent form of this is the miracle and the means of this is grace and those who would administer it (angels, the minister, or their agents, in both religious and political senses).

A theological genealogy of the economy and government could follow the trajectory of providence forward toward Pascal's discussion of 'sufficient grace' and Malebranche's treatise on nature and grace in the late-seventeenth century and thence to the modern theory of democratic 'general will' 
formulated by Rousseau, on the one hand, and to the idea of l'ordre naturel of the Physiocrats on the other (Agamben, 2011: 262-273, 280-285). While its paradigmatic appearance is often thought to be Smith's 'invisible hand' (Hill, 2001), which appears as noted before in both providentialist and naturalist formulations, other important ones can be found. Reverend T.R. Malthus's (1982: 200-217) famous theodicy concerning the vice and misery caused by the tendency of the rate of growth of human population to outstrip its means of subsistence is of a more explicit Christian variety. The problem of government in such a framework becomes how the providential laws of the growth of population and subsistence teach us to align our individual conduct and our mode of public government with them. It was in such a vein that Malthus argued for the abolition of poor relief as encouraging the poor to improvidently procreate, and, later, in favour of individual 'moral restraint' from such procreation. In order to avoid the catastrophic outcomes, such as war, famine and epidemics that would otherwise maintain an equilibrium of population and subsistence, and the vice of unnatural sex and birth control, both government and self-governing individuals would need to conduct themselves with unremitting labour, foresight, prudence and restraint (Tellmann, 2013; Dean, 1991, 2015). The ever-perilous fate of humankind often becomes the occasion for relearning this lesson, or at least for preaching it again. Milton Friedman's (2005) final intervention into public debate after Hurricane Katrina illustrated just this. In almost exactly Schmittian terms, he saw this 'emergency' as requiring a 'political miracle' to overcome the opposition of unions and to create a voucher system to extend the market regime of 'charter schools' in Louisiana and thus act as a 'large-scale example of what the market can do for education when permitted to operate'. The emergency becomes the miracle that through God's grace we can learn to act in accordance with the providence of the market. 
Neither way of approaching the present implies a necessary theological continuity. It is rather a matter of identifying exemplars, like Kuhnian paradigms (Agamben, 2011: 11-12), that are a condition of innovation and experimentation. But the ruptures at each point in the series are never total, given that concepts such as order and providence continue to act as signatures that move fields of concepts across multiple domains without materially altering the relations of which they are a part. The thesis thus advanced is that oikonomia, providence and order, having answered questions about divine rule and human salvation for almost two millennia, relatively recently entered into the service of modern civil government and thence the liberal and neoliberal arts of government in the form of an economic rationality.

\section{Whither the political?}

This paper argued for and exemplified economic theology as an analytical strategy with two arms, an institutional economic theology that investigates the relationship between the ecclesiastical economy of the pastorate and the market economy and a conceptual economic theology that investigates the transfer of concepts under signatures such as of oikonomia, order and providence, from ancient household economics through the Christian tradition to modern economicgovernmental discourses. It considered the theological impossibility of 'economic theology' via the lessons of the Schmitt-Peterson debate on the closure of political theology, arguing that economic theology is both the arcana of twentieth-century debates on political theology and a key to understanding contemporary political action as liturgy. Archaeology recovers the archai preceding the 'moment of arising' or 'emergence' of the split of economy and theology, that allow us to grasp the fundamental figure of economic governing that is conducted in relation to a productive and generative field of immanence in a vicarious fashion on behalf a transcendent domain of providential sovereignty manifest in natural laws, ideal forms and orders. From an economic- 
theological point of view, the transcendent unity, however, is not the source of economic governing but that which the latter presupposes as its necessary foundation.

This paper has addressed the question of the relationship between economic theology and political theology not as a fundamental opposition but rather as a field of relations, tensions and fusing between two poles. As an impolitical theology, economic theology stands in opposition to political theology while itself remaining political. One movement within this field is the neutralization of the political by which political questions of the good life are converted into apparently unpolitical ones of economic management. The theological genealogy supports the critique of Schmitt's 'strongest version of the secularization thesis' (Blumenberg, 1985: 92). That critique has shown - after, as we have seen, Peterson, but also Kantorowicz and Jan Assman (Herrero, 2017: 36-37) - how there can be a theological adoption of political/economic concepts as well as the reverse. Economic theology defines a field of possibilities, not a unilinear historical process. But perhaps the more challenging question is: if a kind of theological economy today has come to occupy much of the domain of the political, to where has Peterson's Christian 'political action' manifest in the liturgies of the Church migrated? One answer is that it remains firmly in the political domain as the assemblies, acclamations, oaths of office, vows, pledges, and ceremonies of democratic public life (Dean, 2017b). Rather than being merely residual symbols, these political liturgies glorify and distribute sovereignty and serve to identify ruler and the ruled. Another part of the answer to that question would be that participatory social media today retain elements of more classical political assembly and religious liturgy, such as acclamation, that have proven amenable to the techniques of manipulation characteristic of 'digital marketing' as witnessed in many of the controversies over the 2016 United States presidential election (Dean, 2017a; 2018). Our present then appears as one caught within a vicious circle between a thorough-going economic neutralization of the political 
and the new liturgical dispositive whose proliferation of acclamations ('liking', 'friending', and other posts) provide the possibility for not simply the manufacture of consent, as it did in the public-opinion formation of the mass media, but also for the 'manufacture of contempt' from the evanescent and volatile swings of public mood recorded on social media. And of course, those acclamations are proving immensely profitable.

The post-structuralist moment in theory with its dispositives and similar figures (the assemblage, the network, even the complex system) fully embraced the 'economic logic' first manifest in the Trinitarian oikonomia. We might say that the early Christians were the first post-structuralists. As a figure of complex, plural, interdependent and heterogeneous elements that nonetheless form a unity ungrounded in an order transcendent to itself, the Holy Trinity marked one of the first of, and perhaps most influential, application of the logic of the dispositive in the Occident. In this respect, poststructuralism proved not only a truly economic theory but also theological one. Unfortunately, as a consequence, that theory was unable to make intelligible the way various dispositives presupposed and constituted a transcendent horizon of, for example, sovereignty, nation, and state, and the practices of glorification that sustain it. It was condemned to assiduously describing the immanent governmental rationalities of contemporary liberalism and thoroughly unable to grasp our challenge today, the relation between such 'economizing' logics that have come to occupy and neutralise the political and the liturgical practices and powers that, it might be said, have gone viral. 


\section{REFERENCES}

Agamben, Giorgio (2009) The Signature of all Things: on Method. New York: Zone Books.

Agamben, Giorgio (2011) The Kingdom and the Glory: for a Theological Genealogy of Economy and Government. Stanford, CA: Stanford University Press.

Arendt, Hannah (1998) The Human Condition (Second Edition). Chicago, IL: University of Chicago Press.

Blumenberg, Hans (1985) The Legitimacy of the Modern Age. Cambridge, MA: MIT Press.

Boethius (1969) The Consolation of Philosophy. Harmondsworth: Penguin.

Boland, Tom and Griffin, Ray (2017) 'The purgatorial ethic and the spirit of welfare', Journal of Classical Sociology, Epub ahead of print August 1 2017. DOI: 10.1177/1468795X17722079.

Carrette, Jeremy (2013) 'Foucault, religion and pastoral power'. In: Falzon, Christopher, O’Leary, Timothy, and Sawicki, Jana (eds) A Companion to Foucault. Chichester: Wiley-Blackwell.

Dean, Mitchell (1991) The Constitution of Poverty: Toward a Genealogy of Liberal Governance. London: Routledge.

Dean, Mitchell (2012) 'Governmentality meets theology: "The king reigns, but he does not govern"”, Theory, Culture \& Society 29 (3): 145-158. 
Dean, Mitchell (2015) 'The Malthus Effect: population and the liberal government of life', Economy \& Society 44 (1): 18-39.

Dean, Mitchell (2017a) 'Political acclamation, social media and the public mood', European Journal of Social Theory 20 (3): 417-434.

Dean, Mitchell (2017b) ‘Three forms of democratic political acclamation', Telos 197: 9-32.

Dean, Mitchell (2018) 'The dark arts reach the internet', TELOSscope, March 27, 2018.

Available at: http://www.telospress.com/the-dark-arts-reach-the-internet/ (Accessed 2 May 2018).

Erlanger, Steve (2018) 'Fight over values risks a "European civil war", Macron says”, New York Times 18 April, 2018.

Available at: https://www.nytimes.com/2018/04/17/world/europe/macron-european-parliamentstrasbourg.html (Accessed 2 May 2018).

Eucken, Walter (1950) The Foundation of Economics. London: William Hodge.

Foucault, Michel (2001) The Essential Works 1954-1984, vol. 3: Power. London: Allen Lane.

Foucault, Michel (2007) Security, Territory, Population, Lectures at the Collège de France, 19771978. London: Palgrave Macmillan. 
Foucault, M. (2008) The Birth of Biopolitics, Lectures at the Collège de France, 1978-1979. London: Palgrave Macmillan.

Friedman, Milton (2005) 'The promise of vouchers', Wall Street Journal, 5 December 2005. Available at:

http://www.edreform.com/Resources/Editorials/?The_Promise_of_Vouchers\&year=2005 (accessed 15 April 2011).

Heron, Nicholas (2018) Liturgical Power: Between Economic and Political Theology. New York: Fordham University Press.

Herrero, Montserrat (2017) 'Sacrament and oath: a theological-political displacement', Political Theology 19(1): 35-49.

Hien, Josef (2017) 'The religious foundations of the European crisis', Journal of Common Market Studies, Epub ahead of print 10 September 2017. DOI: 10.1111/jcms.12635

Hill, Lisa (2001) 'The hidden theology of Adam Smith', European Journal of the History of Economy Thought 8 (1): 1-29.

Hill, Lisa (2006) The Passionate Society: the Social, Political and Moral Thought of Adam Ferguson. Dordrecht: Springer. 
Kantorowicz, Ernst H. (1946) Laudes Regiae: a Study in Liturgical Acclamations and Mediaeval Ruler Worship. Berkeley, CA: University of California Press.

Kantorowicz, Ernst H. (1955) 'Mysteries of state: an Absolutist concept and its late mediaeval origins', Harvard Theological Review 48 (1): 65-91.

Konings, Martjn (2016) ‘The spirit of austerity’, Journal of Cultural Economy 9 (1): 86-100.

Leshem, Dotan (2016) The Origins of Neoliberalism: Modeling the Economy from Jesus to Foucault. New York: Columbia University Press.

Malthus, Thomas (1982) An Essay on the Principle of Population. Harmondsworth: Penguin.

Mondzain, Marie-José (2005) Image, Icon, Economy: the Byzantine Origins of the Contemporary Imaginary. Stanford, CA: Stanford University Press.

Nelson, Robert H. (2004) 'What is economic theology?', Princeton Seminary Bulletin (New Series) 25 (1): 58-79.

Nelson, Robert H. (2017) Lutheranism and the Nordic Spirit of Social Democracy: a Different Protestant Ethic. Aarhus: Aarhus University Press.

Palaver, Wolfgang (2017) 'Faith and trust'. Paper presented at Economic Theology Workshop, Copenhagen Business School, July 8-10. 
Peterson, Erik (2011) Theological Tractates. Stanford, CA: Stanford University Press.

Ptak, Ralf (2009) 'Neoliberalism in Germany: revisiting the Ordoliberal foundations of the social market economy'. In: Mirowski, Philip and Plehwe (eds) The Road from Mont Pèlerin: the Making of the Neoliberal Thought Collective. Cambridge, MA: Harvard University Press.

Rust, Jennifer (2017) 'The stripping of the altars', Syndicate, 22 February 2017. Available at: https://syndicate.network/symposia/theology/the-origins-of-neoliberalism/ (accessed 5 May 2017).

Rüstow, Alexander von (1942) 'Appendix: general sociological causes of the economic disintegration and possibilities of reconstruction'. In: Röpke, Wilhelm, International Economic Disintegration. London: William Hodge.

Schmitt, Carl (1996) Roman Catholicism and Political Form. Westport, CT: Greenwood Press.

Schmitt, Carl (2004) On the Three Types of Juristic Thought. Westport, CT: Praeger Press.

Schmitt, Carl (2005) Political Theology: Four Chapters on the Concept of Sovereignty. Chicago: University of Chicago Press.

Singh, Devin (2015) 'Eusebius as political theologian: the legend continues', Harvard Theological Review 108 (1): 129-154. 
Singh, Devin (2018) Divine Currency: The Theological Power of Money in the West. Stanford, CA: Stanford University Press.

Smith, Adam (1976) An Inquiry into the Nature and Causes of the Wealth of Nations, 2 vols. London: Oxford University Press.

Smith, Adam (2002) The Theory of Moral Sentiments. Cambridge: Cambridge University Press.

Tellmann, Ute (2013) 'Catastrophic populations and the fear of the future - Malthus and the genealogy of liberal economy', Theory, Culture \& Society 30 (2): 132-155.

Ulmen, G. L. (1985) 'The sociology of the state: Carl Schmitt and Max Weber', State, Culture, and Society 1 (2): 3-57.

Ulmen, Gary (1996) 'Introduction'. In: Schmitt, Carl, Roman Catholicism and Political Form. Westport, CT: Greenwood Pres.

Weber, Max (1948) 'The social psychology of world religions'. In: Gerth, H.H., and Mills, C. Wright (eds) From Max Weber. London: Routledge and Kegan Paul.

Weber, Max (1985) The Protestant Ethic and the Spirit of Capitalism. London: Unwin. 
Whyte, Jessica (2013) “"The king reigns but he does not govern”: thinking sovereignty and government with Agamben, Rousseau and Foucault'. In: Frost, Tom (ed.) Giorgio Agamben: Legal, Political and Philosophical Perspectives. London: Routledge. 
Mitchell Dean is Professor of Public Governance at the Copenhagen Business School. He is the author of the well-known Governmentality: Power and Rule in Modern Society (2nd edition, Sage, 2010). His recent books have included The Signature of Power: Sovereignty, Governmentality and Biopolitics (Sage, 2013) and (with Kaspar Villadsen) State Phobia and Civil Society: The Political Legacy of Michel Foucault (Stanford University Press, 2016). He is currently working on political liturgies, acclamation and oaths, and on the search for a left governmentality.

Mitchell Dean

Department of Management, Politics and Philosophy

Copenhagen Business School

Frederiksberg 2000

Denmark

md.mpp@cbs.dk 